

\section{KFG Working Paper Series}

Edited by Heike Krieger, Georg Nolte and Andreas Zimmermann

- Georg Nolte has not acted as editor with respect to the present Working Paper.

All KFG Working Papers are available on the KFG website at www.kfg-intlaw.de.

Copyright remains with the authors.

Gulati, Rishi, Judicial Independence at International Courts and Tribunals: Lessons drawn from the Experiences of the International Court of Justice and the Appellate Body of the World Trade Organisation, KFG Working Paper Series, No. 41, Berlin Potsdam Research Group “The International Rule of Law - Rise or Decline?", Berlin, January 2020.

ISSN 2509-3770 (Internet)

ISSN 2509-3762 (Print)

This publication has been funded by the German Research Foundation (DFG)

Product of Freie Universität Berlin

Commercial use is not permitted

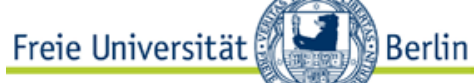

Berlin Potsdam Research Group

International Law - Rise or Decline?

Habelschwerdter Allee $34 a$

14195 Berlin

info@kfg-intlaw.de

+49 (0)30 838-61521

www.kfg-intlaw.de 


\title{
Judicial Independence at International Courts and Tribunals:
} Lessons drawn from the Experiences of the International Court of Justice and the Appellate Body of the World Trade Organisation?

\author{
Rishi Gulati* \\ This publication is forthcoming in Eric De Brabandere (ed), Comparative Procedure in \\ Interstate Litigation (2020)
}

\begin{abstract}
:
The guarantee of judicial independence is undoubtedly one of the most important institutional design features of international courts and tribunals. An independence deficit can adversely impact a court's authority, create a crisis of legitimacy, and undermine the very effectiveness of an international court or tribunal. It can hardly be denied that for an international court to be considered legitimate, a basic degree of independence is a must. An independent judiciary is a precondition to the fair and just resolution of legal disputes. In the context of interstate dispute settlement where the jurisdiction of courts is based on the principle of consent, in the absence of a basic degree of judicial independence, states may not be willing to submit to the jurisdiction of international courts. Comparing and contrasting the International Court of Justice and the Appellate Body of the World Trade Organisation, I assess whether those international judicial mechanisms possess the basic degree of independence required for a court to be able to maintain its credibility so that it can continue to perform its core function of adjudicating interstate disputes. With both those interstate adjudicative bodies constituting the two leading international courts in terms of participation and the sheer number of cases decided, much may be learned from comparing them. I argue there is a case for bolstering the independence of the ICJ; and without immediate reforms to the Appellate Body's institutional design, its recent demise may become permanent. I conclude that if a basic degree of judicial independence cannot be guaranteed, it is preferable to let a court vanish for a while than to maintain a significantly deficient one.
\end{abstract}

\footnotetext{
* Dr. Rishi Gulati is a Fellow in Law at the London School of Economics and Political Science.
} 


\section{Contents:}

1. Introduction

2. Judicial Independence Generally ..............................................................................................................5

3. The Specific Criteria to Assess Judicial Independence ...............................................................................8

a) The Meaning of Operational Independence .............................................................................

b) The Meaning of Decisional Independence ............................................................................10

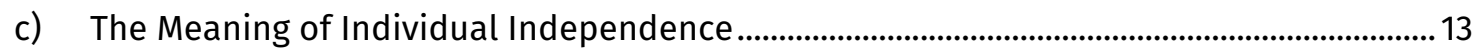

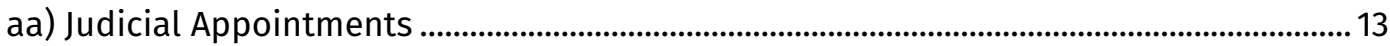

bb) Security of Tenure .................................................................................................................... 15

4. Comparing and Contrasting Judicial Independence at the ICJ and the Appellate Body.............16

a) Comparing and Contrasting Operational Independence............................................................. 17

b) Comparing and Contrasting Decisional Independence ...........................................................21

c) Comparing and Contrasting Individual Independence ......................................................25

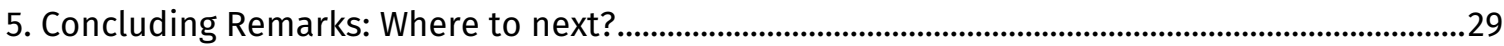




\section{Introduction}

The guarantee of judicial independence is undoubtedly one of the most important institutional design features of international courts and tribunals. ${ }^{1}$ An independence deficit can adversely impact a court's authority, create a crisis of legitimacy, and undermine the very effectiveness of an international court or tribunal. ${ }^{2}$ The debate about how much independence international courts should actually enjoy from the states that create them for them to be 'effective' is subject to much debate. ${ }^{3}$ Despite the contours of that debate, it can hardly be denied that for an international court to be considered legitimate, a basic degree of independence is a must. An independent judiciary is a precondition to the fair and just resolution of legal disputes. ${ }^{4}$ In the context of interstate dispute settlement where the jurisdiction of courts is based on the principle of consent, in the absence of a basic degree of judicial independence, states may not be willing to submit to the jurisdiction of international courts. As a former judge of the International Court of Justice ('ICJ'), Sir Kenneth Keith has put it, states' 'willingness to give and maintain that consent must in major part be based on their assessment that the judges who will decide the disputes will act independently with the necessary impartiality, intellectual competence, qualifications and professional experience, and following a fair procedure. ${ }^{5}$

Comparing and contrasting the ICJ and the Appellate Body of the World Trade Organisation ('Appellate Body' or 'AB'), I assess whether those international judicial mechanisms possess the basic degree of independence required for a court to be able to maintain its credibility so that it can continue to perform its core function of adjudicating interstate disputes. With both those interstate adjudicative bodies constituting the two leading international courts in terms of participation and the sheer number of cases decided, ${ }^{6}$ much may be learned from comparing them. I start by considering what the concept of judicial independence means in general (2.) and how it can specifically be assessed (3.). The chapter then considers whether the ICJ and AB possess the basic degree of independence necessary to properly discharge the judicial function (4.). In pointing out that real deficits exist, I argue there is a case for bolstering the independence of the IC); and without immediate reforms to the AB's institutional design, its recent demise is likely to become permanent. I conclude that if a basic degree of judicial independence cannot be guaranteed, it is preferable to let a court vanish for a while than to maintain a significantly deficient one (5.).

\section{Judicial Independence Generally}

The concept of judicial independence requires that a court or tribunal must make decisions based on the merits of the case and not on any ulterior motives or political considerations. Judicial independence triggers considerations around the judiciary's structural design, with the central demand being that the executive and the legislature (which roughly equate to the executive and policy organs of international organisations under whose umbrella several international courts are

\footnotetext{
${ }^{1}$ See generally, J.L. Dunoff \& M.A. Pollack, 'The Judicial Trilemma', (2017) 111 AJIL 225, at 225-276.

${ }^{2}$ See Y. Shany, Assessing the Effectiveness of International Courts (2014), at 200.

${ }^{3}$ See the discussion in E.A. Posner \& J.C. Yoo, 'Judicial Independence in International Tribunals', (2005) 93 California Law Review 1, at 72; and L.R. Helfer \& A. Slaughter, 'Why States Create International Tribunals: A Response to Professors Posner and Yoo', (2005) 93 California Law Review 899; also see ibid., at 97-116.

${ }^{4}$ See K. Keith, 'Challenges to the Independence of the International Judiciary', 2014 (November) Chatham House. ${ }^{5}$ Ibid.

${ }^{6}$ See sections 3.b) and 4.a) below.
} 
set up) must not interfere in the performance of the judicial function. ${ }^{7}$ This concept, referred to as the separation of powers, is fundamental to the rule of law. ${ }^{8}$ Although a strict separation of powers at the international level is absent when compared to some domestic legal orders, ${ }^{9}$ the spirit of that doctrine is said to apply at the international level too, especially when it comes to ensuring the independence of the international judiciary. In the context of questions relating to the independence of the investment tribunal created to hear investment disputes under the Comprehensive Economic and Trade Agreement between Canada and the European Union (CETA), the European Court of Justice ('CJEU') helpfully explained:

\begin{abstract}
The requirement of independence is, for its part, inherent in the task of adjudication and has two aspects. The first aspect, which is external in nature, presupposes that the body concerned exercises its functions wholly autonomously, without being subject to any hierarchical constraint or subordinated to any other body and without taking orders or instructions from any source whatsoever, thus being protected against external interventions or pressure liable to impair the independent judgment of its members and to influence their decisions. That essential freedom from such external factors requires certain guarantees appropriate for protecting the person of those who have the task of adjudicating in a dispute...The second aspect, which is internal in nature, is linked to impartiality and seeks to ensure that an equal distance is maintained from the parties to the proceedings and their respective interests with regard to the subject matter of those proceedings. That aspect requires objectivity and the absence of any interest in the outcome of the proceedings apart from the strict application of the rule of law. ${ }^{10}$
\end{abstract}

It is the external notion of judicial independence that this chapter is concerned with given its broader relevance to the structural design of an international adjudicatory body. Where precisely the criteria for this external aspect of judicial independence may be found is an important question. A significant amount of case law by supranational human rights courts and monitoring mechanisms exists with respect to the meaning of judicial independence in the context of international human rights law in general and the right to a fair trial in particular. ${ }^{11}$ This jurisprudence has direct applicability to the standards of independence to be maintained in domestic courts. While those standards of

\footnotetext{
${ }^{7}$ See Study Group of the International Law Association on Practice and Procedure of International Courts and Tribunals, and the Project on International Courts and Tribunals, 'The Burgh House Principles on the Independence of the International Judiciary' (2004), at https://www.ucl.ac.uk/internationalcourts/sites/international-courts/files/burgh_final_21204.pdf, ('Burgh House Principles'), paras. 1.1 and 1.2; Montreal Declaration: Universal Declaration on the Independence of Justice (adopted on 10 June 1983), at https://www.icj.org/wp-content/uploads/2016/02/Montreal-Declaration.pdf, ('Montreal Declaration'), paras. 1.02, 1.03 and 1.07; Seventh United Nations Congress on the Prevention of Crime and the Treatment of Offenders, UNGA Res 40/32 ( 6 September 1985, adopted 29 November 1985) (40 th session, $96^{\text {th }}$ meeting) UN Doc A/RES/40/32 ('Basic Principles'), at para. 1. Also see, the discussion in S. Charnovitz, 'Judicial Independence in the World Trade Organization in International Organizations and International Dispute Settlement: Trends and Perspectives' in L. Boisson de Chazournes, C.P.R. Romano and R. Mackenzie (eds.) International Organizations and international dispute settlement (2002), 219-240, at 225.

${ }^{8}$ A. Nollkaemper, National Courts and the International Rule of Law (2011), 54.

${ }^{9}$ Ibid.; also see generally, C. Mollers, The Three Branches (2013), 151.

${ }^{10}$ CJEU Opinion 1/17, Full Court, (30 April 2019), paras. 202-203. This paper does not consider issues of judicial impartiality, which the CJEU refers to as the internal aspect of judicial independence. Those issues have attracted some academic attention: see for example, the contributions of C. Giorgetti, The Challenge and Recusal of Judges of the International Court of Justice, (2015), 3; and G.J. Spak and R. Kendler, 'Selection and Recusal in the WTO Dispute Settlement System' in C. Giorgetti (ed.) Challenges and Recusals of Judges and Arbitrators in International Courts and Tribunals (2015), 164.
}

${ }^{11}$ A. Clooney \& P. Webb, The Right to a Fair Trial in International Law (2020) (forthcoming) 
independence can be useful to measure judicial independence for courts in general, it is beneficial to have regard to a broader range of sources when understanding what the concept of judicial independence in international interstate adjudication may actually entail in particular.

The principles and standards created and endorsed by the international community and international professional bodies are of much significance for they have been created following detailed and lengthy deliberations, reflect basic concepts of independence, and mutually reinforce each other. Those standards are primarily contained in the: International Bar Association's Minimum Standards of Judicial Independence 1982 ('IBA Standards'); ${ }^{12}$ United Nations Basic Principles on the Independence of the Judiciary, 1985 ('Basic Principles'); ${ }^{13}$ the Bangalore Principles of Judicial Conduct 2002 ('Bangalore Principles'); ${ }^{14}$ Commonwealth (Latimer House) Principles on the Three Branches of Government 2003 ('Commonwealth Principles'); ${ }^{15}$ and the Burgh House Principles on the Independence of the International Judiciary 2004 ('Burgh House Principles'). ${ }^{16}$ The Burgh House Principles have especially been developed in light of the particularities of international courts and tribunals. ${ }^{17}$

While the Burgh House Principles have direct relevance to the work of international courts and tribunals, ${ }^{18}$ as was clarified in the Universal Declaration on the Independence of Justice 1983 ('Montreal Declaration'), ${ }^{19}$ the principles of independence applicable in the national context, also apply internationally, of course with appropriate adjustments. ${ }^{20} \mathrm{It}$ is particularly notable that while national judges require independence from the legislative and executive branches, for international courts, independence must be maintained from a varied set of potential external bodies and pressures. The Burgh House Principles clarify in their preambular paragraphs, 'to ensure the independence of the judiciary, judges must enjoy independence from the parties to cases before them, their own states of nationality or residence, the host countries in which they serve (that is why international judges tend to possess immunities), ${ }^{21}$ and the international organisations under the auspices of which the court or tribunal is established'. With the above context and sources in mind, I now move on to determine the specific criteria against which the independence of an international court can and should be measured.

\footnotetext{
${ }^{12}$ International Bar Association, ‘IBA Minimum Standards of Judicial Independence’ (1982), at https://www.ibanet .org/Document/Default.aspx?DocumentUid=10917543-8F09-4A68-8324-9228BB6237A1, ('IBA Standards').

${ }^{13}$ Basic Principles, supra note 7.

${ }^{14}$ Judicial Group on Strengthening Judicial Integrity, 'The Bangalore Draft Code of Judicial Conduct', (2002) at https:// www.unodc.org/pdf/crime/corruption/judicial_group/Bangalore_principles.pdf, ('Bangalore Principles').

${ }^{15}$ The Commonwealth, 'Latimer House Principles: Practitioner's Handbook', (2017) at http://thecommonwealth. org/sites/default/files/news-items/documents/LatimerHousePrinciplesPH7)ul17.pdf ('Commonwealth Principles').

${ }^{16}$ Burgh House Principles, supra note 7.

${ }^{17}$ Ibid., Preamble.

18 Ibid., Preamble and Principle 1.2.

${ }^{19}$ Montreal Declaration, supra note 7.

${ }^{20}$ Ibid., paras. 1.06 and 1.07.

${ }^{21}$ Statute of the International Court of Justice, (1945), 3 Bevans 1179, 59 Stat 1055, TS No 993 ('ICJ Statute'), Art. 19; the Appellate Body members do not seem to possess immunities in respect of their functions.
} 


\title{
3. The Specific Criteria to Assess Judicial Independence
}

The external aspect of judicial independence is best understood through the lenses of institutional and individual independence. ${ }^{22}$ Institutional independence requires that the judiciary at large must be independent from external bodies and pressures. ${ }^{23}$ This particularly requires: 'operational independence' (involving both administrative and financial independence (a)); and decisional independence (b)). ${ }^{24}$ Judicial independence not only requires the independence of the judiciary at large, but also the presence of guarantees pertaining to the independence of individual judges. Individual independence demands the personal and substantive independence of individual judges. ${ }^{25}$ Personal independence means that the terms and conditions of judicial service are adequately secured. ${ }^{26}$ Substantive independence demands that individual judges "have a right and a duty to decide cases before them according to law, free from outside interference including the threat of reprisals and personal criticism. ${ }^{27}$ Individual independence can helpfully be grouped into issues around the mode of judicial appointment and all facets of the security of tenure (c)).

Both, institutional and individual independence should be present to ensure overall judicial independence in its external dimension. In other words, for the judiciary/judges to be considered independent, both guarantees of institutional and individual independence must be present at the same time. The Commentary to the Bangalore Principles explain:

\begin{abstract}
Judicial independence refers to both the individual and the institutional independence required for decision-making. Judicial independence is, therefore, both a state of mind and a set of institutional and operational arrangements. The former is concerned with the judge's independence in fact; the latter with defining the relationships between the judiciary and others...so as to assure both the reality and the appearance of independence. The relationship between these two aspects of judicial independence is that an individual judge may possess that state of mind, but if the court over which he or she presides is not independent of the other branches of government in what is essential to its functions, the judge cannot be said to be independent. ${ }^{28}$
\end{abstract}

It is thus important to take a holistic view when assessing the level of independence of a court, taking into account both, institutional and individual factors. Without a broad perspective, the picture remains incomplete. The following discussion briefly lays down what operational, decisional and individual independence mean; and then the situation at the ICJ and the $A B$ are compared and contrasted with reference to those criteria.

\footnotetext{
22 Bangalore Principles, supra note 14, Value 1; Commonwealth Principles, supra note 15, Principle IV.

${ }^{23}$ See for example, IBA Standards, supra note 12, para. 2.

${ }^{24}$ For a helpful summary of these criteria, see International Bar Association, Human Rights in the Administration of Justice: A Manual on Human Rights for Judges, Prosecutors and Lawyers (2003), 119-120, ('OHCHR Report').

${ }^{25}$ IBA Standards, supra note 13, para. 1.

${ }^{26}$ Ibid. para. 1(b); Basic Principles, supra note 7, para. 11; Bangalore Principles, supra note 15, Value 1.1; Montreal Declaration, supra note 7, para. 2.2.

${ }^{27}$ OHCHR Report, supra note 25, at 133; see IBA Standards, supra note 13, para. 1(c).

${ }^{28}$ United Nations Office on Drugs and Crime, 'Commentary on the Bangalore Principles of Judicial Independence' (2007, September), para. 23.
} 


\section{a) The Meaning of Operational Independence}

Operational independence (administrative and financial independence) is necessary to maintain the judiciary's autonomy, including from any policy and executive organ of an international organisation where a court may be located. ${ }^{29}$ For the IC], such organs would include the General Assembly and the Security Council; and for the $A B$, they would be the political organ of the World Trade Organisation (WTO), i.e. the General Council (which manifests itself as the Dispute Settlement Body ('DSB') when performing its functions under the Dispute Settlement Understanding of the WTO ('DSU')). ${ }^{30}$ As Shany has explained, operational independence constitutes a set of structural factors that create the factual situation that promote the ability of international courts to 'exercise their judicial power without undue influence'. ${ }^{31}$ He goes on to explain why operational independence is crucial to avoid undue influence on courts and tribunals: "[w] that reasonable budgets are secured well ahead of time for court operations and for payment of decent judicial salaries, courts and judges are less vulnerable to interference by their financial sponsors, who might issue explicit or implicit threats of immediately withdrawing financial support if certain outcomes are not reached'. ${ }^{32}$

Given the structural significance of operational independence, it is unsurprising that it is one of the foremost principles found in the Burgh House Principles. Principle 1.2 of the Burgh House Principles states that "[w]here a court is established as an organ or under the auspices of an international organisation, the court and judges shall exercise their judicial functions free from interference from other organs or authorities of that organisation. This freedom shall apply...to the operation of the court and its registry.' Overall, to secure a sufficient degree of operational independence, autonomy should exist with respect to both administrative and financial matters, which can of course lead to an overlap. As to the former, Principle 1.3 of the Burgh House Principles relevantly states:

The court shall be free to determine the conditions for its internal administration, including staff recruitment policy, information systems and allocation of budgetary expenditure.

As to the latter, the judiciary should be adequately funded so that it can perform its functions effectively, and without external interference. The Burgh House Principles provide in Principle 6:

\footnotetext{
${ }^{29}$ IBA Standards, supra note 13, para. 7; Montreal Declaration, supra note 7, para. 2.40; Burgh House Principles, supra note 7, paras. 1.2 and 1.3.

${ }^{30}$ See L. Bartels, 'The Separation of Powers in the WTO: How to Avoid Judicial Activism' (2004) 53 International and Comparative Law Quarterly 861, at 863-864, where the author helpfully explains that at the WTO, at the 'apex is the Ministerial Conference...[which] has the power to take decisions on all matters under any of the multilateral WTO agreements...On a day-to-day basis, the full authority of the Ministerial Conference is exercised by the General Council...The General Council also convenes as the Dispute Settlement Body when exercising its functions under the Dispute Settlement Understanding...In this capacity, it operates with its own Chairman and under its own rules of procedure. The DSB takes decisions by consensus...The primary responsibilities of the DSB are 'to establish panels, adopt panel and Appellate Body reports, maintain surveillance of implementation of rulings and recommendations, and authorize suspension of concessions and other obligations under the covered agreements'; see Understanding on rules and procedures governing the settlement of disputes, April 15 1994, Ann. 2, WTO Agreement: Marrakesh Agreement Establishing the World Trade Organization, 15 April 1994, 1867 U.N.T.S. 14, 33 I.L.M. 1143 (1994), ('WTO Dispute Settlement Understanding' or 'DSU'), Art. 2.1.

${ }^{31}$ Shany, supra note 2, at 101.

32 Ibid.
} 
States parties and international organisations shall provide adequate resources, including facilities and levels of staffing, to enable courts and the judges to perform their functions effectively. ${ }^{33}$

What is apparent is that operational (administrative and financial) independence may be grouped into two specific aspects: (1) the need for an adequate level of funding; and (2) non-interference into matters of administration and allocation of budgetary expenditure. Such matters also involve analysing the role of the registry which has a substantive impact on organising and directing a court's operations. Any undue interference in the work of the registry can undermine trust as well as the institutional independence of a court. Cartier and Hoss have noted:

\begin{abstract}
[A]ll Registries and Legal Secretariats (RLS), as organs of the judicial institutions, play an indispensable role in inspiring trust in their institution by interacting with the parties in a fair and effective manner, in the midst of conflicting views and interests. Parties are more likely to accept adverse findings if they believe that their case was handled with utmost care, not only by individual judges, but also by those with whom they are in regular contact at RLS. This is true in any international judicial institution, such as inter-state courts, international criminal courts, and human rights courts. A fair, strictly neutral, and discrete RLS greatly contributes to generating trust in any judicial institution. ${ }^{34}$
\end{abstract}

In the present context, what will be therefore assessed is the ICJ's and AB's administrative and financial independence (including of their registries) from amongst others, the other organs of the United Nations (UN) and WTO respectively. Should the latter exert the kind of administrative or financial control over the former so as to undermine their autonomy, then the judicial mechanism in question cannot be said to be institutionally independent. Based on this brief review, the principles underpinning operational independence seem fairly straightforward. However, as we will see later (4.a) below), it is the application of these principles to the practical circumstances of a court that involves considerable nuance. Adjudicative bodies generally (may they be domestic or international) rely on outside funding; there are almost always budgetary constraints under which a legislative/policy making organ operates (noting especially the perennial budgetary crisis at the UN, and the systemic budgetary issues at the WTO); ${ }^{35}$ and thus practically realising operational independence can present real challenges requiring a fine balancing exercise.

\title{
b) The Meaning of Decisional Independence
}

The UN Basic Principles provide a neat list of the three matters pertinent to ensuring decisional independence. First, Basic Principle 2 states that the "judiciary shall decide matters before them impartially, on the basis of facts and in accordance with the law, without any restrictions, improper influences, inducements, pressures, threats or interferences, direct or indirect, from any quarter or for any reason'. The guarantees that evidence and enhance decisional independence include (but are not limited to) the presence of a clear legal basis on which a dispute is to be resolved (thus

\footnotetext{
${ }^{33}$ Also see IBA Standards, supra note 13, para. 7; Basic Principles, supra note 7, para. 7; Commonwealth Principles, supra note 16, Principle IV(c); Montreal Declaration, supra note 7, para. 2.41.

${ }^{34}$ S. Cartier and C. Hoss, 'The Role of Registries and Legal Secretariats in International Judicial Institutions' in C.P.R. Romano, Y. Shany \& K. Alter (eds.) The Oxford Handbook of International Adjudication (2014), 712.

${ }^{35}$ See, Shany, supra note 2, at 211 (regarding the WTO); and for the most recent crisis at the UN, see https://www.independent.co.uk/news/world/un-budget-deficit-united-nations-money-cash-flow-memberstates-antonio-guterres-a8465906.html.
} 
limiting judicial adventurism and reducing the risk of impartial behaviour); presence of fact-finding authority; ${ }^{36}$ presence of express guarantees of 'fairness' in the conduct of the proceeding; ${ }^{37}$ and properly reasoned judicial decisions. ${ }^{38}$ Concerning this last factor, a properly reasoned decision can do much to show that a particular decision is based on the facts and law of a case as opposed to impermissible external pressures.

Second, Principle 3 of the Basic Principle states that the "judiciary shall have jurisdiction over all issues of a judicial nature and shall have exclusive authority to decide whether an issue submitted for its decision is within its competence as defined by law'. This criterion requires that a court should be able to autonomously and conclusively determine its own jurisdiction. ${ }^{39}$ The topic of jurisdiction is one of the most vexing questions faced by international law in general, and international courts in particular. No exhaustive treatment of those topics is presently undertaken. The aim is to simply identify the state of decisional independence of the ICJ and the $A B$ in light of their current jurisdictional scheme as opposed to an idealised version of it. However, to provide the necessary context, it is important to briefly explain what 'jurisdiction' in the present sense means.

International courts and tribunals are created by agreement amongst states and do not possess plenary jurisdiction. The adjudicative jurisdiction of an international court is only triggered if there is 'consent' by a state to subject itself to the relevant court's authority. In the absence of consent, the jurisdiction of an international court does not exist. Assuming consent can be established, further jurisdictional criteria must be satisfied. These are (1) Jurisdiction ratione personae or personal jurisdiction (who can be party to a case); (2) jurisdiction ratione materiae or subject-matter jurisdiction (what issues can a court decide); (3) jurisdiction ratione temporis or temporal jurisdiction (when did the dispute in question arise); and (4) jurisdiction ratione loci or spatial/territorial jurisdiction (where did the events in question occur). ${ }^{40}$ If any of these jurisdictional criteria are not established, an international court's jurisdiction cannot exist.

When assessing the decisional independence of international courts, it is important to bear in mind that the autonomy that an international court has vis-à-vis the cases it can hear and determine is fairly limited. Even in respect of the IC), the principal judicial organ of the UN (also known as the World Court), roughly two thirds of the UN member states have not subscribed to its compulsory jurisdiction under Article 36(2) of the ICJ Statute, and many of those who have done so have made extensive reservations. ${ }^{41}$ This limits the compulsory as well as personal, subject matter and territorial

\footnotetext{
36 'A guaranteed capacity to generate facts that have been independently evaluated, either through a third-party factfinding process or through the public contestation inherent in the adversary system, helps counter the perception of self-serving or “political” judgments': see L.R. Helfer \& A.M. Slaughter, Toward a Theory of Effective Supranational Adjudication, 303.

${ }^{37}$ See A. Sarvarian, F. Fontanelli, R. Baker \& V. Tzevelekos, Procedural Fairness in International Courts and Tribunals (2015), especially chapter 13; and in the specific context of international administrative tribunals, see R. Gulati, 'An International Administrative Procedural Law of Fair Trial: Reality or Rhetoric?' in 21 Max Planck Yearbook of United Nations Law (2018), 210-270.

${ }^{38}$ Helfer \& Slaughter, supra note 37, at 318.

${ }^{39}$ See Basic Principles, supra note 7, para. 3 that states: 'The judiciary shall have jurisdiction over all issues of a judicial nature and shall have exclusive authority to decide whether an issue submitted for its decision is within its competence as defined by law'; also see Montreal Declaration, supra note 7, para. 2.5.

${ }^{40}$ For an excellent analysis of grounds of jurisdiction (including issues around admissibility), see generally, Y. Shany, 'Jurisdiction and Admissibility' in the Oxford Handbook of International Adjudication, 781.

${ }_{41}$ ICJ Statute, supra note 21, Art. 36(2); for a detailed analysis, see A. Zimmermann, C.J. Tams, K. Oellers-Frahm \& C. Tomuschat, The Statute of the International Court of Justice (3rd Edition): A Commentary, (2019), at 719. The list
} 
jurisdiction of the ICJ considerably. The ICJ in fact hears a significant number of cases where jurisdiction is based on special agreement (ad hoc agreement) or due to the presence of a jurisdictional clause in a particular treaty regime (compromissory clause). ${ }^{42}$ The extent to which IC) jurisdiction is not compulsory, it may be better characterised as a somewhat 'dependent court'. ${ }^{43}$ On the other hand, as far as the $A B$ is concerned, while its subject matter jurisdiction is limited to trade disputes falling within the purview of WTO law $^{44}$ (within those limits though, its jurisdiction is broad), ${ }^{45}$ it is termed as a less 'dependent court' for within the field of its activity, it possesses compulsory jurisdiction over all WTO member states (which consist of 164 states) ${ }^{46}$ making its personal jurisdiction truly broad. As we will see later (at 4.b) and 4.c) below), the enhanced independence created at the $A B$ in light of its compulsory jurisdiction has caused a backlash that has resulted in a real threat to its very existence for a key state; the United States is openly displeased with certain $A B$ decisions and has actively sought to undermine that body.

Be that as it may, the point of note for this purpose is that different international courts possess distinctive jurisdictional schemes. It is not the intention presently to critique which particular scheme is superior or more effective; the aim is to simply assess whether the selected judicial mechanisms possess the decisional independence necessary for them to be considered institutionally independent within the sphere of their particular judicial activity. Bearing this in mind, for a court to be considered institutionally independent, it must have the ability to autonomously and independently determine jurisdictional matters. In other words, the court must possess the jurisdiction to determine its own jurisdiction (compétence de la compétence). ${ }^{47}$ The assessment does not involve considering how a particular court understands the scope of its own jurisdiction; as long as it can autonomously determine questions about its own jurisdiction, decisional independence would exist.

Third, Basic Principle 4 states that 'there shall not be any inappropriate or unwarranted interference with the judicial process'. Not only should an international court have the capacity to adjudicate on its own jurisdiction, but fundamentally, this means that judicial decisions should be respected and

of the 74 states who have accepted the compulsory jurisdiction of the ICJ (including texts of reservations) are available at https://www.icj-cij.org/en/declarations.

${ }^{42}$ Art. 36(1) of the ICJ Statute, supra note 21, states: 'The jurisdiction of the Court comprises all cases which the parties refer to it and all matters specially provided for in the Charter of the United Nations or in treaties and conventions in force.'

${ }^{43}$ Posner \& Yoo, supra note 3, at 36. The same authors say at 12-13 that '[i]ndependence exists when judges have fixed terms and are not appointed by the parties of a dispute...In addition, jurisdiction must be compulsory, or states will simply deny jurisdiction of a court when they believe they are likely to lose.'

${ }^{44}$ Art. 23(1) of the DSU provides for compulsory and exclusive jurisdiction applying to all disputes arising between WTO members under the covered agreements. These agreements include the WTO Agreement: Marrakesh Agreement Establishing the World Trade Organization, 15 April 1994, 1867 U.N.T.S. 14, 33 I.L.M. 1143 (1994) ('WTO Agreement'); GATT 1994: General Agreement on Tariffs and Trade 1994, 15 April 1994, WTO Agreement, Annex 1A, 1867 U.N.T.S. 187, 33 I.L.M. 1153 (1994) ('GATT’); the individual multilateral agreements on trade in goods; GATS: General Agreement on Trade in Services, 15 April 1994, WTO Agreement, Annex 1B, 1869 U.N.T.S. 183, 33 I.L.M. 1167 (1994) ('GATS'); TRIPS: Agreement on Trade-Related Aspects of Intellectual Property Rights, 15 April 1994, WTO Agreement, Annex 1C, 1869 U.N.T.S. 299, 33 I.L.M. 1197 (1994) ('TRIPS'); and DSU, Art. 1(1).

${ }^{45}$ See Shany, supra note 2, at 196-197 (WTO tribunals can hear cases on the alleged violation of covered agreements; non-violation cases and situation complaints).

${ }^{46}$ See https://www.wto.org/english/thewto_e/whatis_e/tif_e/org6_e.htm.

${ }^{47}$ For a useful exposition of the compétence de la compétence principle, see Prosecutor v Dusko Tadić (Dec. on the Defence Motion for Interlocutory Appeal on Jurisdiction) case no IT-94-1-AR72 (1996) 35 ILM 32, paras. 9-64. 
enforced, with the judiciary having the ability to supervise the enforcement process. ${ }^{48}$ The analysis in this chapter assesses decisional independence primarily based on the de jure guarantees relating to the finality and bindingness of the decisions of the selected adjudicative mechanisms. This method is well justified for any non-compliance with a court decision is less a matter of structural design of a given court as such (the focus of this chapter), but is rather a broader and systemic problem in the international legal order being an issue outside the scope of this work.

\section{c) The Meaning of Individual Independence}

The two broad categories to assess individual independence currently adopted (2. above) are the process of judicial appointment, for it is at this stage that issues around the personal and substantive independence of judges may be already significantly impacted on (especially issues around competence) (3.c) aa)); and issues around the security of tenure (3.c) bb)).

\section{aa) Judicial Appointments}

Who appoints judges, and how and on what basis judges are appointed, constitute the central matters of concern under this head. ${ }^{49}$ To uphold the doctrine of separation of powers, it is increasingly considered that the executive or legislature (or comparable organs in international organisations charged with selecting/electing international judges) ought to have a minimal role in the selection and appointment of judges. And that only appropriately qualified persons be appointed to judicial office. On the former, if a legislative or executive organ or a particular member state had undue influence on the appointment process, then serious questions about the motives behind the appointment could be raised..$^{50}$ Principle 10 of the UN Basic Principles relevantly states:

Persons selected for judicial office shall be individuals of integrity and ability with appropriate training or qualifications in law. Any method of judicial selection shall safeguard against judicial appointments for improper motives.

While judicial appointments made by an executive or legislative organ alone may not automatically cause the breach of the principle of individual independence, ${ }^{51}$ the greater their role, the more

\footnotetext{
${ }^{48}$ IBA Standards, supra note 13, para. 7; Basic Principles, supra note 7, para. 4; Montreal Declaration, supra note 7, para. 2.47.

49 Traditionally, there are no strict criteria regarding the method of appointments or qualifications for appointment required. For method of appointment, see IBA Standards, supra note 13, para. 3 (appointments should preferably be done by bodies comprising of members of the judiciary); Montreal Declaration, supra note 7, para. 2.12 states that judicial appointments should be non-discriminatory allowing for nationality to be a criterion for appointments to international courts. For requirements on qualifications: see IBA Standards, supra note 13, para. 26 (only appointments based on merit are permissible); Basic Principles, supra note 7, para. 10 requires that: 'Persons selected for judicial office shall be individuals of integrity and ability with appropriate training or qualifications in law. Any method of judicial selection shall safeguard against judicial appointments for improper motives....'

50 See for example, Human Rights Committee, Views: Communication No 486/1991, UN Doc CCPR/C/49/D/468/1991 (1993) ('Ol Bahamonde v Equatorial Guinea'), para 5.1: The complainant claimed that the judges in Equatorial Guinea could not 'act independently or impartially, since all judges and magistrates were directly nominated by the President.' At para. 9.4, the Committee found that 'a situation where the functions and competencies of the judiciary and the executive are not clearly distinguishable or where the latter is able to control or direct the former is incompatible with the notion of an independent tribunal.'

${ }^{51}$ E. Cannon \& I. Warlam, 'The Judicial Independence Of The International Labour Organization Administrative Tribunal: Potential For Reform', (2007) Amsterdam International Law Clinic ('Amsterdam Report'), 34-35: 'In sum, the jurisprudence confirms that while appointment by the executive is not in itself cause to question the
} 
scrutiny ought to be given when issues of independence are engaged. In such cases, other safeguards mitigating the independence deficit caused by the appointment process should be enacted, for instance, by providing for strong guarantees regarding the security of tenure. ${ }^{52}$

To remove the risk of an improper motive in the appointment of judges, transparency is critical. Principle IV(a) of the Commonwealth Principles provides that to achieve judicial independence 'appointments should be made on the basis of clearly defined criteria and by a publicly declared process', where 'merit and proven integrity' are the criteria of eligibility for appointment to public office. ${ }^{53}$ Similarly, Principle 2.3 of the Burgh House Principles states that '[i]nformation regarding the nomination, election and appointment process and information about candidates for judicial office should be made public, in due time and in an effective manner, by the international organisation or other body responsible for the nomination, election and appointment process.' Although stated in the domestic context, emphasising the need for transparency and independence in the appointment process, it has been noted:

It is now relatively uncommon for judicial appointments to be in the hands of the executive alone, without the involvement of any other public body in selecting or shortlisting candidates...Executive-only appointment systems require a combination of legal safe-guards and settled political conventions in order to be a reliable and legitimate means of appointing judges. The precise mix may differ between jurisdictions, but should include at least transparency regarding the criteria for appointment and the procedures followed, a requirement of consultation with senior judges and others, and ideally the existence of an independent body to provide oversight and deal with complaints. ${ }^{54}$

The spirit of the above provision ought to equally apply in the international context. Transparent processes that are independent of any executive or legislative organ or states in the appointment of judges are required to ensure that judicial appointments are not based on ulterior motives; and greatly assist in ensuring that meritorious candidates are identified. Obviously, it is inevitable that states do and will continue to play a role in the appointment of international judges. However, there ought to exist a meaningful and substantive role for an expert body to identify suitable candidates transparently and with the necessary autonomy to ensure that the most meritorious candidates are ultimately appointed to high judicial office.

In this latter respect, judicial appointments must be made on merit and based on legal qualifications as the primary consideration..$^{55}$ This requires that individuals appointed to judicial office are well qualified. Without relevant experience and minimum qualifications required before an individual

independence of a tribunal, such a circumstance should be counter-balanced with guarantees that insure the independence of the tribunal at hand.'

52 Human Rights Committee, 'Consideration of Reports Submitted by States Parties under Art. 40 of the Covenant - Concluding Observations of the Human Rights Committee - Slovakia', UN Doc CCPR/C/79/Add.79 (1997), para. 18. In Lauko v. Slovakia, Dec. of 19 October 1995, ECHR (App no 26138/95), the combination of appointment by the executive and the "lack of any guarantees against outside pressures and any appearance of independence" led the Court to conclude that the bodies in question could not be considered to be independent of the executive.

${ }^{53}$ Commonwealth Principles, supra note 16, Principle V(a).

${ }^{54}$ Ibid.; also see Burgh House Principles, supra note 7, Principle 2.22.

${ }^{55}$ The Human Rights Committee has said that judges should be selected primarily on the grounds of their legal qualifications: Human Rights Committee, 'Consideration of Reports Submitted by States Parties under Art. 40 of the Covenant - Concluding Observations of the Human Rights Committee - Sudan', UN Doc CCPR/C/79/Add.85 (1997), para. 21. 
may be considered for a judicial role, concerns about the personal and substantive independence of a judge can be raised, alongside questions whether a judge can discharge his or her role 'competently'. If an individual lacks competence, it is less likely that he or she will be able to discharge the responsibilities of judicial office without external pressures impacting his or her decision. Indeed, the statutes of the judicial mechanisms presently the subject of assessment do possess some generalised competence requirements: ${ }^{56}$ whether or not they are fully implemented is a different issue (at 4.c) below). Encapsulating the need to ensure that merit is the key criterion for judicial appointment, the Burgh House Principles provide in Principle 2.1:

[J]udges shall be chosen from among persons of high moral character, integrity and conscientiousness who possess the appropriate professional qualifications, competence and experience required for the court concerned. While procedures for nomination, election and appointment should consider fair representation of different geographic regions and the principal legal systems, as appropriate, as well as of female and male judges, appropriate personal and professional qualifications must be the overriding consideration in the nomination, election and appointment of judges.

\section{bb) Security of Tenure}

The length of a judge's term is key to assessing individual independence, with guaranteed tenure necessary to ensure individual independence. Short renewable terms tend to decrease independence; and relatively longer non-renewable terms enhance it. ${ }^{57}$ The assumption that a judge would wish for his or her term to be renewed is an obvious one. That being the case, subconsciously or perhaps on occasions consciously, a judge's decision making may be compromised. Instead of basing the decision on the law and facts of a given case, the decision may be driven by ulterior motives, jeopardising the individual independence of a judge. ${ }^{58}$ Following an extensive analysis that included interviews with several judges from various international courts and tribunals, Dunoff and Pollack reach the conclusion that longer terms which cannot be renewed maximise judicial independence. ${ }^{59}$ Notably, the reasons for creating nine year non-renewable terms for the judges of the European Court of Human Rights were rooted in the need for enhanced independence. An Evaluation Group appointed by the Council of Europe to assess the working of the European Court of Human Rights had said:

In its own case-law, the Court requires of national courts a high standard of objective independence and impartiality, extending also to appearances.... The Evaluation Group

\footnotetext{
${ }^{56}$ Art. 2 of the ICJ Statute, supra note 21, provides that: 'The Court shall be composed of a body of independent judges, elected regardless of their nationality from among persons of high moral character, who possess the qualifications required in their respective countries for appointment to the highest judicial offices, or are jurisconsults of recognized competence in international law'; and Art. 17(3) of the DSU provides: 'The Appellate Body shall comprise persons of recognized authority, with demonstrated expertise in law, international trade and the subject matter of the covered agreements generally. They shall be unaffiliated with any government. The Appellate Body membership shall be broadly representative of membership in the WTO. All persons serving on the Appellate Body shall be available at all times and on short notice, and shall stay abreast of dispute settlement activities and other relevant activities of the WTO. They shall not participate in the consideration of any disputes that would create a direct or indirect conflict of interest.'

${ }^{57}$ See generally Dunoff \& Pollack, supra note 1, at 225-276.

${ }^{58}$ In this regard, see especially Burgh House Principles, supra note 7, paras. 3.1 and 3.2. Para. 3.2 provides that: 'The governing instruments of each court should provide for judges to be appointed for a minimum term to enable them to exercise their judicial functions in an independent manner.'

${ }^{59}$ See generally Dunoff \& Pollack, supra note 1, at 225-276 (especially at 237-238).
} 
considers that the Convention should be amended so as to lay down that judges of the Court are elected for a single, fixed term, without possibility of re-election. This term should not be less than nine years. The effect of these changes would be to ensure continuity within the Court and, moreover, to offer a further guarantee of the Court's independence. ${ }^{60}$

Implementing relatively lengthy non-renewable tenures ought to then be the ideal standard for judicial appointments at international courts. At the very least, the length of a term should be sufficiently long to reduce the risk of compromising individual independence. An example of good practice is provided by the UN's own new internal justice system which has created seven year nonrenewable terms for the judges of the United Nations Dispute Tribunal. ${ }^{61}$

Moreover, the financial security of a judge is also necessary to maintain individual independence. Generally, judicial salaries and pension rights ought not to be subject to reduction for such a threat of action or its carrying out may compromise the financial security of judges, creating a risk that decisions adverse to a particular party are not made for fear of retaliation. ${ }^{62}$ As a recent commentary to the Commonwealth Principles explain:

The Commonwealth Latimer House Principles declare that 'appropriate security of tenure and protection of levels of remuneration must be in place' in relation to the judiciary. Such guarantees serve to shield judges from external pressures and conflicts of interest when they hold powerful individuals or government bodies legally to account...'judicial salaries and benefits should be set by an independent body and their value should be maintained'. ${ }^{63}$

Finally, it is crucial that the process of removing judges from office is properly regulated. If the political organs of international organisations are able to remove a judge from office without good cause (such as for reasons of judicial misconduct) and in the absence of a fair hearing for a judge, the individual independence is compromised. The Burgh House Principles relevantly provide in Principle 17 that:

\begin{abstract}
[e]ach court shall establish rules of procedure to address a specific complaint of misconduct or breach of duty on the part of a judge that may affect independence or impartiality...In any case where the court determines that fuller investigation is required, the rules shall establish adequate safeguards to protect the judges' rights and interests and to ensure appropriate confidentiality of the proceedings. The governing instruments of the court shall provide for appropriate measures, including the removal from office of a judge.
\end{abstract}

\title{
4. Comparing and Contrasting Judicial Independence at the ICJ and the Appellate Body
}

Now that the task of setting out the key criteria against which the independence of the selected regimes should be assessed has been undertaken, the chapter will compare and contrast the ICJ and $A B$ regimes in accordance with those criteria. The discussion especially focuses on issues where

\footnotetext{
${ }^{60}$ J. Harman (Chair of Evaluation Group), 'Report of the Evaluation Group to the Committee of Ministers on the European Court of Human Rights', (2001) reproduced in Steering Committee for Human Rights (CDDH), Reforming the European Convention on Human Rights: A Work in Progress (2009), para. 89.

${ }^{61}$ For a detailed study on the UNDT, see Gulati, supra note 38.

${ }^{62}$ See Burgh House Principles, supra note 7, para. 4.2; IBA Standards, supra note 13, para. 15(b); Commonwealth Principles, supra note 16, Principle IV(b); Montreal Declaration, supra note 7, para. 1.14.

${ }^{63} \mathrm{~J}$. van Zyl Smit, 'The Appointment, Tenure and Removal of Judges under Commonwealth Principles: A Compendium and Analysis of Best Practice', (2015) British Institute of International and Comparative Law, 19-20.
} 
independence deficits are particularly stark. In doing so, the aim is to draw lessons learnt from each of those regimes and suggest a way forward.

\section{a) Comparing and Contrasting Operational Independence}

Judging whether the ICJ and the $A B$ constitute operationally independent courts require an analysis of their administrative and financial arrangements. As far as the operational independence of the ICJ is concerned, what should be born in mind is that the court constitutes not only a principal organ of the UN, but also the principal judicial organ of the UN. ${ }^{64}$ The ICJ's operational arrangements reflect this duality. More specifically, the recognition of the ICJ's 'independence is not to be found in specific articles in the UN Charter but rather by necessary implication', and is underpinned also by several exchanges of letters between the President of the court and the UN Secretary General. ${ }^{65}$ Particularly, in assessing operational independence, as was said (3.a) above), it is important to consider the working of a court's registry, being the office responsible for the court's administration.

The ICJ's Registry is led by a Registrar who is supported by a Deputy Registrar and around 100 staff members. ${ }^{66}$ Reflecting the duality referred to above, the Registry and the Registrar perform a diplomatic, judicial support, and administrative role (including preparing and administering the court's budget under the direction of the court's Administrative and Budgetary Committee). ${ }^{67}$ It is this latter function that is of present relevance. While the registrar of the ICJ is considered to be the head of administration, the Registrar exercises this authority under the supervision and control of the President and the Court. ${ }^{68}$ The Registrar would tend to possess minimum qualifications and experiences in the field of law, international organisations or diplomacy; ${ }^{69}$ is appointed for renewable seven year terms demonstrating a degree of stability and independence; ${ }^{70}$ and does not report to any other UN organ or official but the ICJ. ${ }^{71}$ Further, all Registry staff report to the Registrar and are governed by rules promulgated by the Registrar. ${ }^{72}$ There must be no interference by other UN organs on issues of staffing or other matters of internal administration. ${ }^{73}$ Regarding budgeting matters, while UN committees (such as the Fifth Committee) and ultimately the UN General Assembly approve the IC)'s budget, ${ }^{74}$ effectively, the responsibility of preparing the budget lies with the IC)

${ }^{64}$ Charter of the United Nations, (1945), 1 UNTS XVI ('UN Charter'), Arts. 7(1) (on the principal organs of the organization), 36(3) (on the pacific settlement of disputes), and 92-96 (on the ICJ); together with Art. 1 ICJ Statute, set out the constitutional position of the ICJ.

${ }^{65}$ R. Higgins, P. Webb, D. Akande, S. Sivakumaran \& J. Sloan, Oppenheim's International Law - United Nations (2017) ('Oppenheim'), at 29.189.

${ }^{66}$ See https://www.icj-cij.org/en/registry.

${ }^{67}$ See ibid.; Rules of the Court: International Court of Justice, Rules of the Court, (14 April 1978) Acts and Documents No. 6 (The Hague, ICJ, 2007) ('ICJ Rules of Court'), Art. 26(3); The administrative and budgetary committee is composed of the president (chair), the vice-president, both ex officio, and four to five judges elected every three years: Cartier \& Hoss, supra note 35, at 717.

${ }^{68}$ Cartier \& Hoss, ibid., at 717. The key administrative decisions are taken by members of the court, the judges, upon recommendation of its administrative and budgetary committee and implemented by the Registrar.

${ }^{69}$ ICJ Rules of Court, supra note 67, Art. 22(3).

70 Ibid., Art. 22(1).

${ }^{71}$ Relatively longer terms for Registrars are also said to enhance the independence of a court, although more research on this topic is needed: Cartier \& Hoss, supra note 35, at 730.

${ }^{72}$ The ICJ also consists of a Rules Committee, as well as other committees performing specific administrative work: Cartier \& Hoss, supra note 35, at 717.

${ }^{73}$ For details on the Registrar's administrative and financial role, see, https://www.icj-cij.org/en/registrar.

${ }^{74}$ ICJ Statute, supra note 21, Art. 32 provides that the expenses of the Court shall be borne by the UN in such a manner as shall be decided by the General Assembly. Under UN Charter, supra note 64, Art. 17, the General 
itself. Once this budget has been prepared and submitted by the court, generally, no changes are made and the budget is approved. ${ }^{75}$ Accordingly, there is a basic degree of operational (administrative and financial) independence entrenched at the IC).

However, there have unfortunately been occasions where the UN has tried to meddle with the ICJ's budgetary affairs, such as by attempting to introduce result-based budgetary allocations. ${ }^{76}$ For a judicial institution, any such move will severely undermine the financial independence of the court. Moreover, certain UN offices (Office of Internal Oversight) have recently conducted external review/audits of the ICJ causing an interference on matters of internal administration. ${ }^{77}$ No doubt, if such interventions become a regular occurrence, the operational independence of the ICJ may be impermissibly compromised. Clearly, ensuring the financial independence of the ICJ is all the more important for it is in 'a different position from that of almost all the other organs, principal and subsidiary, of the UN. It does not work on programmes which can be postponed or abandoned at will, as has occurred when the UN found itself in financial difficulties'. ${ }^{78}$

An instinctively attractive proposition to further bolster the ICJ's operational independence could be to recalibrate how it is established in international law by transforming the court into a treaty based international organisation in its own right. Leaving to one side the practical obstacles, any such move will have its own risks for member states of international organisations can still intrude into a court's independent functioning. In the absence of compelling evidence that the IC)'s operational independence has been compromised, the better view is to ensure the independent functioning of the ICJ within the UN system. This can principally be achieved by more informed and transparent coordination between the ICJ and other UN organs, where the role of the ICJ as an independent judicial organ is better understood by the latter when making decisions with respect to the court's operations. ${ }^{79}$ International organisations of course regularly face financial pressures and ensuring adequate resourcing are questions of fine balance. That being said, any interference with the allocation of budgetary expenditure should be strictly prohibited. It ought to be left to the ICJ to conduct its affairs efficiently and cost-effectively. To maintain operational independence, it is the IC) that must initiate independent and regular audits into its functioning as opposed to intrusions from other UN organs.

Despite some hiccups, the ICJ's operational independence is well reflected in its regulatory setup, with the court benefiting from detailed prefatory discussions that led to its creation. ${ }^{80}$ On the other hand, the Appellate Body has witnessed an organic development. The AB (created in 1995) is the premier judicial mechanism established within the regime of the WTO to resolve interstate trade

\footnotetext{
Assembly shall consider and approve the budget of the UN. The expenses are to be borne by the members of the UN in such proportion as the General Assembly shall decide, and under UN Charter, supra note 64, Art. 18(2), budgetary questions are included in the list of 'important questions' requiring in the General Assembly a twothirds majority of the members present and voting. In the UN, apart from the Secretariat which prepares the budget and submits it to the General Assembly, organs specially concerned with the administrative and financial matters include the Advisory Committee on Administrative and Budgetary Questions, the Joint Inspection Unit, and the Fifth Committee (Administrative and Budgetary Questions) of the General Assembly.

${ }^{75}$ Oppenheim, supra note 66.

${ }^{76}$ See S. Rosenne, 'International Court of Justice' (2006) in R Wolfrum (ed.), Max Planck Encyclopedia of Public International Law, para. 52.

${ }^{77}$ Oppenheim, supra note 66, section 29.191 .

${ }^{78} \mathrm{lbid}$.

$79 \mathrm{lbid}$., section 29.17 (notes that such understanding is often lacking).

${ }^{80}$ See generally, Rosenne, supra note 77 .
} 
related disputes, and was established pursuant to the WTO's Dispute Settlement Understanding. ${ }^{81}$ It transformed the largely diplomatic dispute resolution system that preceded it, i.e. the era of the General Agreement on Tariffs and Trade ('GATT'). The DSU creates a two tier dispute resolution system, where a 'panel' consisting of non-professional judges (some requirements of judicial independence are loosely prescribed) determines questions of fact and law. ${ }^{82}$ Significantly, the DSU also creates the ability of a dissatisfied party to seek review of a panel's report at the Appellate Body, but only on questions of law. ${ }^{83}$

At the time of its creation, the Appellate Body was considered as a kind of 'afterthought', ${ }^{84}$ 'a kind of safety valve against a rare panel ruling that was seriously anomalous in terms of the general institutional understanding of the legal norms at issue'. ${ }^{85}$ Initially, the WTO membership expected that recourse to the $A B$ would be required infrequently so as to correct the findings of a recalcitrant panel. ${ }^{86}$ With the $A B$ deciding 155 cases since its inception thus far, ${ }^{87}$ making it one of the most used international dispute resolution mechanisms, recent history has demonstrated otherwise. As Howse explains, the $A B$ has established its independence from other organs of the WTO by various rulings. The $A B$ has: adopted a textualist and formalist approach to its decisions guided by the Vienna Convention on the Law of Treaties 1969; developed a doctrine of implicit judicial powers (for example, it has allowed amicus curiae briefs); emphasised the precedential weight of $A B$ reports; allowed representation by private counsel; adopted a practice of consensus rulings; etc. ${ }^{88}$ Therefore, the $A B$ has clearly established itself as a judicial body. Despite the presence of certain atypical features for a judiciary, such as the requirement that $A B$ reports must be adopted by the DSB (a political body) in order to be binding (an issue I will shortly return to), that the AB (and perhaps even WTO panels) (together referred to as 'WTO tribunals') constitute a judicial mechanism. As has been said, in 'determining claims, WTO Tribunals act independently, much like international courts. They fix the boundaries of the dispute before them, marshal the evidence, determine the appropriate law, apply that law to the facts, and reach a decision.' ${ }^{89}$

Given that the $A B$ has (almost all) features of a judicial mechanism, the standards against which its independence should be judged must be thus the same as that would apply to any other international court or tribunal. In respect of the AB's operational independence, it is startlingly compromised. This is the case both de jure and de facto. On the situation de jure, firstly, on administrative independence, unlike the ICJ, there are no detailed rules where the role and functions of the AB's Secretariat/Registry are enshrined, with $A B$ members seemingly not possessing control

\footnotetext{
${ }^{81}$ The Appellate Body was established in 1995 under Art. 17 of the Understanding on Rules and Procedures Governing the Settlement of Disputes, LT/UR/A-2/DS/U/1 (1994). For a background, see J.H. Jackson, 'The Evolution of the World Trading System - The Legal and Institutional Context' in D. Bethlehem, I. Van Damme, D. McRae \& R. Neufeld (eds.) The Oxford Handbook of International Trade Law (2009), 31-50.

82 DSU, Arts. 8 and 11; R. Howse, 'The World Trade Organization 20 Years On: Global Governance by Judiciary' (2016) 27 EJIL 1, at 21.

${ }^{83}$ DSU, Art. 17(6).

${ }^{84}$ See generally, P. van den Bossche, 'From Afterthought to Centrepiece: The Appellate Body and Its Rise to Prominence in the World Trading System' in G. Sacerdoti, A. Yanovich and J. Bohanes (eds.), The WTO at Ten: The Contribution of the Dispute Settlement System (2006), at 289.

${ }^{85}$ Howse, supra note 83 , at 26.

${ }^{86}$ Ibid.

${ }^{87}$ See https://www.wto.org/english/tratop_e/dispu_e/ab_reports_e.htm.

${ }^{88}$ Howse, supra note 83 , at 31.

${ }^{89}$ A. D. Mitchell \& D. Heaton, 'The Inherent Jurisdiction of WTO Tribunals: The Select Application of Public International Law Required by the Judicial Function' (2010) 31 Mich. J. Int'l L. 559, at 566.
} 
on administrative and financial matters. ${ }^{90}$ It also appears that the Director-General of the WTO has a significant role in selecting the Director of the AB's Secretariat (effectively the AB's Registrar) and its staff, with no input from the $A B$ 's members. ${ }^{91}$ Secondly, on financial independence, there appear to be no provisions establishing the AB's independence on budgetary matters, with the General Council (a political organ) responsible for preparing the $A B$ 's budget. Overall, there is little transparency regarding the administrative and financial independence of the $A B$. As other commentators have noted, the lack of transparency at the WTO is a real concern due to the 'accountability problem'. ${ }^{92}$

Crucially, regarding the situation de facto, the practice of both, the panel and the AB should be commented upon together for it is the former that solely decides questions of fact thus shaping the dispute, with the latter only possessing the ability to determine questions of law. In this respect, the broader operational independence of the WTO dispute resolution machinery is compromised. In a rather critical assessment, Howse has said:

\begin{abstract}
While it is clear from the DSU that the intention was to draw the Appellate Body membership from distinguished respected jurists, the panel system was not professionalized. Panellists are mostly low or mid-level trade officials or retired officials, many are not lawyers and few have trial advocacy experience. The WTO Secretariat remains crucial in orienting the panel reports and motivating them through extensive reasons and citations of authority. There is essentially no distance or independence of the panellists from the WTO insider community; legal advisers from the WTO Secretariat are usually present throughout the panel's proceedings and deliberations. By establishing appellate review only for error of law and giving appellate review a very tight timeline (60 to 90 days), the Uruguay Round negotiators virtually guaranteed that a factual basis determined by essentially amateur adjudicators and technocrats within the WTO bureaucracy would be decisive in framing the disputes. ${ }^{93}$
\end{abstract}

The WTO's political organs possess significant operational control over the justice machinery making the latter an operationally dependent mechanism. What explains (but does not justify) this laxity is that unlike the ICJ which was created following considerable deliberation, the AB was an afterthought which was not expected to become the judicial body that it now is. With no substantive structural reforms made to the $A B$ since its creation, it is hardly surprising that the $A B$ itself is now in crisis. The lesson to be drawn from the comparison undertaken is an obvious one. Where a court's institutional design attracts a proper and full deliberation at the time of its creation, operational independence may be largely ensured. However, where there is a lack of deliberation, especially where the judicial mechanism's development is organic, without significant structural reform operational independence is difficult (if not impossible) to realise.

\footnotetext{
${ }^{90}$ See Art. 17(7)-(8), DSU: '7. The Appellate Body shall be provided with appropriate administrative and legal support as it requires. 8. The expenses of persons serving on the Appellate Body, including travel and subsistence allowance, shall be met from the WTO budget in accordance with criteria to be adopted by the General Council, based on recommendations of the Committee on Budget, Finance and Administration.'

${ }^{91}$ According to recommendations made by the Preparatory Committee of the WTO, which were approved by the WTO Dispute Settlement Body (DSB) in February 1995, it is incumbent upon the "Director-General of the WTO, in consultation with the Chairman of the DSB," to select the "support staff," which presumably include the registrar, the legal officers, and administrative assistants: Cartier \& Hoss, supra note 35, at 729.

${ }^{92}$ Cartier \& Hoss, supra note 35, at 729.

${ }^{93}$ Howse, supra note 83 , at 21.
} 


\section{b) Comparing and Contrasting Decisional Independence}

In so far as the first set of criteria for measuring decisional independence is concerned, i.e, that the judiciary must decide cases impartially, on the basis of the facts and the law, and without any external pressures, factors such as the presence of a clear legal basis on which disputes are to be resolved, presence of fact-finding capacity, presence of general guarantees of fairness and the provision of reasons, are just some independence enhancing factors (3.b) above). Comparing the ICJ and $A B$ regimes, Article 38 of the ICJ Statute and Article 3 of the DSU respectively provide for the applicable law regime for these judicial mechanisms. ${ }^{94}$ It is true that Article 38 of the ICJ Statute has attracted countless publications as to the sources of international law; and the interaction between general international law and WTO law is not entirely clear. ${ }^{95}$ However, for the purposes of the present assessment, a basic degree of clarity as to the applicable law regimes demonstrably exists in both the ICJ and $A B$ regimes, with judges bound to determine cases in accordance with a prescribed legal regime.

Concerning fact-finding, the ICJ Statute grants the court the power to make factual findings and evidence-gathering powers. ${ }^{96}$ In this respect, the ICJ has demonstrated considerable decisional independence, both in its contentious and advisory jurisdiction. Even where complex factual questions are at stake, the court has proceeded to exercise jurisdiction in contentious cases (see for example the Nicaragua case ${ }^{97}$ where the United States' argument that the ICJ was incapable of determining complex factual questions in connection to an armed conflict was readily rejected)..$^{98}$ This is also the case in terms of the exercise of the IC)'s advisory jurisdiction under Article 65 of its Statute. Telling are the ICJ's views delivered in its 2019 Chagos Advisory Opinion. ${ }^{99}$ In response to the contention that the issues raised complex factual issues which are not suitable for determination in advisory proceedings, the ICJ said:

The Court recalls that in its Advisory Opinion on Western Sahara when it was faced with the same argument, it concluded that what was decisive was whether it had "sufficient information and evidence to enable it to arrive at a judicial conclusion upon any disputed questions of fact the determination of which is necessary for it to give an opinion in conditions compatible with its judicial character"...Moreover, the Court recalls that, in its Advisory Opinion on Legal

\footnotetext{
${ }^{94}$ Art. 38(1) of the ICJ Statute, supra note 21, provides that The Court shall resolve disputes applying a. international conventions; b. international custom; c. the general principles of law; $d$. judicial decisions and the teachings of the most highly qualified publicists; Art. 3(2) of the DSU states: 'The dispute settlement system of the WTO is a central element in providing security and predictability to the multilateral trading system. The Members recognize that it serves to preserve the rights and obligations of Members under the covered agreements, and to clarify the existing provisions of those agreements in accordance with customary rules of interpretation of public international law. Recommendations and rulings of the DSB cannot add to or diminish the rights and obligations provided in the covered agreements.'

${ }^{95}$ Note, however, that there exists a debate about the extent to which general international law applies in adjudication by the WTO tribunals: see generally, A. Lindroos \& M. Mehling, 'Dispelling the Chimera of 'SelfContained Regimes': International Law and the WTO' (2006) 16 EJIL 857, at 861-866; also see, Shany, supra note 2, at 196-197, where he says: 'The establishment of a de facto system of precedent by WTO adjudicators (though no formal doctrine of stare decisis exists under the DSU), further fortifies the DSS capacity to promote the security and predictability of the multilateral regime.'

${ }^{96}$ ICJ Statute, supra note 21, Arts. 48-50.

${ }_{97}$ Military and Paramilitary Activities in and Against Nicaragua (Nicaragua v United States of America), Jurisdiction and Admissibility, Judgment of 26 November 1984, ICJ Rep. 392.

${ }_{98}$ Ibid., paras. 99-101.

${ }^{99}$ Legal Consequences of the Separation of the Chagos Archipelago from Mauritius in 1965, Advisory Opinion of 25 February 2019, ICJ GL No 169.
} 
Consequences for States of the Continued Presence of South Africa in Namibia (South West Africa)...it held that "to enable [it] to pronounce on legal questions, it must also be acquainted with, take into account and, if necessary, make findings as to the relevant factual issues" 100

While the ICJ clearly possesses fact-finding powers enhancing its decisional independence, this cannot be said of the AB. De jure, what is fatal to the AB's decisional independence is its inability to decide on questions of fact. ${ }^{101}$ As was stated at (3) above, only WTO panels are legally entitled to make factual findings, meaning that a body that objectively lacks independence decides questions of fact, shapes the dispute, and the $A B$ is not legally empowered to disturb factual findings that may be suspect. This means that within the WTO's dispute resolution machinery, there is no truly independent judicial body that is empowered to make factual determinations. The only possible way to remedy this shortcoming would be either: (a) to modernise the panel system making it a truly genuine first instance judicial mechanism; or (b) grant the AB greater powers. Without significant reform the $A B$ 's decisional independence will continue to be compromised.

Finally, the topic of 'fairness' of proceedings (an issue to which several recent works have been dedicated) is a distinct and broad topic in its own right and no comment is passed here. ${ }^{102}$ It is however worth noting briefly that both, the ICJ and $A B$ render detailed decisions on each case they decide and all decisions are published. ${ }^{103}$ Interestingly, the ICJ's Statute allows for separate and dissenting opinions ${ }^{104}$ (a practice which is transparency enhancing); and $A B$ decisions in large part are unanimous, and remarkably a judge's identity is not revealed, ${ }^{105}$ making the $A B$ a less transparent adjudicative mechanism. Despite these variations, the fact that both, the ICJ and the AB provide reasoned judgments does satisfy the basic degree of structural independence required in an international judicial mechanism. The intricacies about whether separate and dissenting opinions are permitted go towards advancing distinct values (independence, transparency and accountability) and may be taken into account when creating or reforming international courts and tribunals in light of legal policy concerns. ${ }^{106}$

Moving on to the second criterion for decisional independence, both the ICJ and $A B$ have demonstrated their autonomy in conclusively determining their own jurisdiction (competence competence); and this they have often done despite upsetting powerful states. Article 36(6) of the ICJ Statute provides de jure decisional independence and states that '[i]n the event of a dispute as to whether the Court has jurisdiction, the matter shall be settled by the decision of the Court'. The ICJ recognised and endorsed the principle of compétence de la compétence already in 1953, when it said 'an international tribunal has the right to decide as to its own jurisdiction and has the power to

\footnotetext{
100 Ibid., paras. 71-72.

101 DSU, Art. 17(6).

102 See for example, Sarvarian et al., supra note 38.

${ }_{103}$ ICJ Statute, supra note 21, Art. 56 and Art. 17(14) (Appellate Body Decs. are known as reports).

104 Ibid., Art. 57.

${ }^{105}$ Art. 17(11) of the DSU states 'Opinions expressed in the Appellate Body report by individuals serving on the Appellate Body shall be anonymous'. As Dunoff \& Pollack, supra note 1, at 261, note, in less than $5 \%$ of AB reports has there been a separate opinion or dissent.

${ }^{106}$ Dunoff \& Pollack, supra note 1, have noted that only two out of the three values of independence (which they define as the freedom of judges to base decisions on law and fact), transparency (mechanisms that help identify decisions of individual judges, through use of separate and dissenting opinions) and accountability (structural checks on judicial authority through reappointment processes) can be maximised at one time.
} 
interpret for this purpose the instruments which govern that jurisdiction.' ${ }^{107}$ In subsequent cases, the ICJ has amply demonstrated its decisional independence. Despite the heated political background in the Nicaragua case which was determined in the context of an armed conflict at the height of the cold war, in rejecting objections to its jurisdiction by the United States on various grounds, the ICJ exhaustively considered the nature and scope of its compulsory jurisdiction under Article 36(2) of its Statute, ultimately deciding against the United States' objections. ${ }^{108}$

In addition to seeking to establish a lack of consent, the United States had also argued that Nicaragua's claims against it were inadmissible and non-justiciable, and that the court lacked subject matter jurisdiction because Nicaragua's claims essentially alleged that the United States were engaged in an unlawful use of armed force against it, and such matters are within the competence of the United Nations Security Council according to the UN Charter. ${ }^{109}$ In rejecting this argument, the IC) simply said that '[i]t must also be remembered that, as the Corfu Channel case...shows, the Court has never shied away from a case brought before it merely because it had political implications'. ${ }^{10}$ Following the decision of the ICJ in Nicaragua, the United States left the compulsory jurisdiction of the court. In yet another example where the court decided against another powerful state, i.e France, after the ICJ decided against that state in the Nuclear Test case, ${ }^{111}$ France also left the compulsory jurisdiction regime of the court.

The ICJ has also shown robust decisional independence with respect to the exercise of its advisory jurisdiction. In all the requests for advisory opinions it has received since its creation, only once has it refused to exercise its jurisdiction despite the charged political contexts in which an advisory opinion may often be sought. ${ }^{112}$ This goes to show that the ICJ possesses and has exercised considerable decisional independence even at the risk of upsetting powerful states. Like the IC), the WTO tribunals have also shown considerable decisional independence when it comes to autonomously determining questions of jurisdiction. Unlike the ICJ which possesses broad subject matter jurisdiction, the WTO AB is an adjudicative body created to determine disputes with respect to a specific subject matter, i.e. trade disputes. In broad strokes, the $A B$ is said to be a decisionally independent court. ${ }^{113}$ Although the principle of compétence de la compétence is not contained in the DSU, based on the inherent powers of WTO tribunals as judicial bodies, ${ }^{114}$ the AB has said:

WTO panels have certain powers that are inherent in their adjudicative function. Notably, panels have the right to determine whether they have jurisdiction in a given case, as well as to determine the scope of their jurisdiction. In this regard, the Appellate Body has previously

\footnotetext{
${ }^{107}$ Nottebohm (Lichtenstein v Guatamala) (1953) ICJ Rep. 111, at 119.

108 Military and Paramilitary Activities in and Against Nicaragua (Nicaragua v United States of America), Jurisdiction and Admissibility, Judgment of 26 November 1984, ICJ Rep. 1984, 392, at para. 47.

${ }^{109}$ Ibid., paras. 89-91.

110 Ibid., para. 96.

${ }^{111}$ Nuclear Tests Case (Australia v. France), Jurisdiction and Admissibility, Judgment of 20 December 1974, ICJ Rep. 1974, at 253.

${ }^{112}$ See Legality of the Use by a State of Nuclear Weapons in Armed Conflict, Advisory Opinion of 8 July 1996, ICJ Rep 66 (where the ICJ refused to exercise its jurisdiction to issue an advisory opinion).

${ }^{113}$ Howse, supra note 83, at 21.

${ }^{114}$ See Legality of Use of Force (Serb. \& Mont. v. Belg.), Judgment of 15 December 2004, ICJ Rep. 279, at 338-339 (Judge Higgins, Separate Opinion), where Judge Higgins has reaffirmed the existence of inherent jurisdiction, stating: 'The Court's inherent jurisdiction derives from its judicial character and the need for powers to regulate matters connected with the administration of justice, not every aspect of which may have been foreseen in the [constitutive instrument of the tribunal].'
} 
stated that "it is a widely accepted rule that an international tribunal is entitled to consider the issue of its own jurisdiction on its own initiative, and to satisfy itself that it has jurisdiction in any case that comes before it." ${ }^{115}$

Similar to the ICJ, WTO tribunals have also not shied away from rendering decisions in highly politically charged situations. In a recent dispute between Russia and Ukraine arising in the context of hostilities between those two countries, Russia imposed transit restrictions on Ukrainian goods passing through its territory contrary to certain WTO obligations; and justified its actions based on the national security exception contained in Article XXI of the General Agreement on Tariffs and Trade (GATT). ${ }^{116}$ Russia argued that the panel lacked jurisdiction, as a WTO tribunal could not adjudicate on matters where the national security exception in the GATT was at issue. In the first decision of its kind, a WTO panel rejected Russia's argument saying that the national security exception was not self-judging after conducting an exhaustive analysis of the negotiating history of that provision. ${ }^{177}$ In doing so, the Panel demonstrated its autonomy in determining the scope of its jurisdiction. ${ }^{118}$ Clearly, both the ICJ and WTO tribunals have manifested considerable decisional independence endorsing the principle of compétence de la compétence. Even at the risk of upsetting powerful states and in charged political situations, they have taken and exercised jurisdiction discharging the judicial function of adjudicating interstate disputes in the sphere of their activity in a decisionally independent manner.

The record on enforceability of decisions, the third criterion for decisional independence, is somewhat mixed if compliance is also taken into consideration. In respect of the enforceability and respect granted to ICJ decisions, despite de jure guarantees in the ICJ Statute that its decisions are binding as between the parties, ${ }^{119}$ the rate of compliance is patchy and difficult to assess. ${ }^{120}$ Posner and Yoo have pointed out that the ICJ faces real difficulties in achieving compliance with its decisions and cite several well-known examples of non-compliance. ${ }^{121}$ Critically though, as was stated (3.b) above), the issue of compliance rates on its own must not detract from the assessment of an international court's decisional independence as such. The fact that, as a matter de jure, ICJ judgements are final and binding; in light of the nature of the international legal order where courts and tribunals do not have access to strong enforcement mechanisms of their own; on balance, the IC) does demonstrate a basic degree of decisional independence so as to be able to continue to discharge its adjudicative functions with credibility.

In respect of the $A B$ 's decisional independence, there do exist de jure guarantees (although somewhat convoluted) regarding the bindingness of $A B$ reports/decisions which become automatically binding pursuant to the reverse consensus rule operating at the DSB. ${ }^{122}$ The process

\footnotetext{
${ }^{115}$ WTO Appellate Body Report, Mexico - Tax Measures on Soft Drinks and Other Beverages, (6 March 2006) WT/DS/308/AB/R, at 45.

116 Ukraine v Russian Federation, Panel Report, DS512: Russia - Measures Concerning Traffic in Transit (5 April 2019).

117 Ibid., paras. 7.27-7.28.

118 Ibid., para. 7.104.

119 ICJ Statute, supra note 21, Art. 59. ICJ provisional measures under Art. 41 are also now considered binding.

${ }^{120}$ See generally, C. Schulte, Compliance with Decisions of the International Court of Justice (2005).

121 Posner \& Yoo, supra note 3, at 39-41.

122 See Art. 17(14), DSU. The DSB is a political body comprising the representatives of the member states and gives valid effect to the decisions disseminated by the WTO tribunals through the adoption of their rulings. Regarding
} 
requires that the report of the Panel (as amended by the $A B$ ) should be adopted 'unless there is a consensus of the members against adoption'. ${ }^{123}$ As the winning party is unlikely to act against its own interests, a decision by the $A B$ is effectively binding.

Some commentators have criticised the WTO dispute resolution machinery for the limits placed on its ability to grant remedies. Howse has said that 'the WTO system make it fall short of a true compliance/enforcement regime. ${ }^{124}$ It has been further commented:

[R]emedies are only prospective. If after exhausting the appellate process a Member finds itself faced with a definitive ruling of violation against it, then its sole obligation is to alter its measure to bring itself into compliance within a reasonable period of time. There are no damages, or reparations, for the harm caused by the offending measure up to the end of the reasonable period of time or whenever it is modified or withdrawn. ${ }^{225}$

Clearly, there exist limitations on what remedies the $A B$ and WTO tribunals can grant. When passing judgment on the decisional independence of the $A B$ though, regard must be had for its institutional design and the agreement reached by states to tailor the relief it may grant in light of the particularities and goals of the broader WTO legal regime. ${ }^{26}$ On its own, the de jure limitations on the kind of relief that the $A B$ is empowered to grant in interstate disputes in a particular subject matter, does not on its own detract from the AB's decisional independence. On the contrary, a highly nuanced scheme on the kind of remedies that may be granted can enable the goal of greater compliance. ${ }^{127}$

On balance, can it be said that the ICJ and $A B$ possess a basic degree of decisional independence when assessed against the selected criteria? While the answer for the ICJ must be in the affirmative, the AB's decisional independence can be significantly enhanced. The treaty-based guarantees provided in the ICJ Statute have enabled it to maintain a high degree of decisional independence. Whereas the $A B$ 's decisional independence has been maintained and promoted by its own initiative, with little protection enshrined in the DSU. This laxity in the DSU, as is shown in the following section, has meant that the AB's decisional independence can actually come under serious threat especially where individual independence is also compromised.

\section{c) Comparing and Contrasting Individual Independence}

The criteria used to measure individual independence relate to the judicial appointment process and security of tenure. On the judicial appointment process, without transparency in the selection

the bindingness of $A B$ reports adopted by the DSB, see, WTO, US-Measures Relating to Zeroing and Sunset Reviews, Report of the Appellate Body (August 31, 2009) WT/DS322/AB/RW, para. 153-157.

${ }^{123} \mathrm{DSU}$, Art. 17(14).

124 Howse, supra note 83 , at $19-20$.

125 Ibid., 19-20.

${ }^{126}$ Note, one central goal of the WTO regime is maintaining the security and predictability of the multilateral trading system: DSU, Art. 3.2.

${ }^{127}$ See Shany, supra note 2, at 191 and 194 (and DSU, Art. 3.7). It is useful to note that Shany also points out that compliance rates are fairly high, albeit varying estimates exist. It has been pointed out that disaggregation of the data on compliance with rulings into full, partial, and no compliance reveals positive compliance rates, 'albeit of a less impressive nature. Thus, Horlick and Coleman find a distribution of $67.1 \%$ full compliance, $24.1 \%$ partial compliance, and $8.9 \%$ no compliance. Epstein et al, however, report about $66 \%$ full compliance, $13 \%$ partial compliance, and 21\% no compliance': Shany, supra note 2, at 213. 
process, qualification criteria, and minimising the influence of political factors, the risk that individual independence may be limited is high (3.C) aa) above). In this respect, the ICJ's practice is suspect. Much ink has been spilt on this particular topic so current observations are limited to matters of highest concern. The mode of election of an ICJ judge is somewhat convoluted. The ICJ consists of 15 judges and no two judges can be of the same nationality. ${ }^{128}$ Elections occur once every three years in a staggered system. ${ }^{129}$ The candidates are nominated by a National Group that exists within the auspices of the Permanent Court of Arbitration ('PCA'). ${ }^{130}$ These national groups are supposed to be independent, however, it has been argued that it is the national government that makes the determination as to whether a particular candidate is nominated. As Alford has pointed out:

The process of election through the national group of the PCA with the approval of the Security Council and the General Assembly was designed to minimize political influence in the nomination process...former Legal Adviser Davis Robinson...candidly admit[ed] that most national groups usually "are extensions of their governments." He did note that the U.S. national group on occasion has displayed streaks of independence, with the choice of Richard Baxter over the Carter Administration's preferred candidate-former Supreme Court Justice Arthur Goldberg-as the most famous example. ${ }^{131}$

Furthermore, as to the requirement of merit, while Article 2 of the IC) Statute prescribes that candidates 'should be persons of high moral character, who possess the qualifications required in their respective countries for appointment to the highest judicial offices, or are jurisconsults of recognized competence in international law', as Mackenzie et al pointed out following an in-depth empirical study, it is politics that often dictates nominations. They conclude:

Our findings show that whether or not individual states are successful in obtaining a seat depends to a considerable extent upon prevailing political and economic power relations and on bilateral agreements between states and regional blocks. Evidence of politicization is apparent at both the nomination and election stages...nomination practices are fragmented, lacking in transparency, and highly varied. At one end of the spectrum, a few candidates emerge following a transparent and formal consultative process that focuses on merit; at the other end, it is not unusual for individuals to be selected as a result of overtly political considerations or even nepotism. Whatever form of nomination process is adopted, all nominated candidates must work their way through a highly politicized election process. ${ }^{132}$

Therefore, powerful states possessing political influence have an inherent advantage in securing appointment of their preferred candidates. The so-called convention that the five permanent members of the Security Council should always have a judge of their nationality at the ICJ (the 'P5 convention') is a stark reminder of this power dynamic. ${ }^{133}$

\footnotetext{
128 ICJ Statute, supra note 21, Art. 3.

129 Ibid., Art. 4(1); for a detailed account of the judicial appointment process at the ICJ, see R. Mackenzie, K. Malleson, P. Martin, and P. Sands, Selecting International Judges: Principle, Process, and Politics (2010).

${ }^{130}$ ICJ Statute, supra note 21, Art. 4(1).

131 See http://opiniojuris.org/2010/06/21/donoghue-confirmed-as-choice-for-icj-vacancy/.

132 Mackenzie et al., supra note 129 , at 173-174.

133 Ibid., 189-190.
} 
Interestingly, in 2017, a dent was made to the so-called P5 Convention. Judge Greenwood's nomination (the United Kingdom's preferred candidate) was withdrawn by the United Kingdom after the Indian nominee, Judge Bhandari was elected for a second term after receiving majority support at the General Assembly and the Security Council. ${ }^{134}$ This was the first time in the court's history that the United Kingdom did not have a judge of its nationality at the ICJ. ${ }^{135}$ That the P5 convention was undermined can only be a positive development as such. Any optimism must be guarded though. The real reason why the Indian candidate prevailed over the United Kingdom candidate had little to do with inherent merit (both candidates were highly qualified), but perhaps more to do with shifting power dynamics in international relations, with states such as India exerting an ever-increasing influence. This episode, when properly understood, reaffirms the power dynamic at play in ICJ elections as opposed to evidence of any principled reform.

In this respect, the experiences of Sir Kenneth Keith who has been willing to speak openly about his appointment to the ICJ are pertinent:

My campaign...lasted for over two years and involved visits to more than 30 capitals as well as to New York three times - but I know it best and I draw two points from it. One is the very heavy commitment a government of a small country like New Zealand undertakes if it is to support a candidate, given that elections to the Western European and Other Group seats are usually fought very vigorously...My second point about the campaign relates to a proposition...'elections of judges should not be subjected to prior bargaining which would make the voting in such elections dependent on votes in other elections'... fear such proposals fly in the face of the facts. Let me tell one story. In a major capital - not a P5 capital I stress - my New Zealand foreign ministry minder and I met a very senior official in their foreign ministry. In a most direct way, he said that in such matters they were concerned with only two issues. Looking at me, he said the first was the quality of the candidate, the individual. I was very well qualified and would be an excellent member of the Court. He wanted to hear no more about that. He then turned to my Foreign Affairs colleague and to his second matter. What is in it for us? ${ }^{136}$

Indeed, if it were not for the convention of geographical distribution operational at the UN/ICJ, less powerful states would have even lower representation on the bench than is currently the case. ${ }^{137}$ In light of the significant deficiencies already pointed to, it is somewhat surprising that there have not been louder and more pressing calls for urgent reforms to the ICJ judicial appointment process. Perhaps the reason being that despite its deficits, the ICJ is well respected as a judicial body and for most part, the independence of judges is not publically attacked. One important (but not the only) factor why this may be the case is due to the relatively lengthy terms that judges enjoy at the court. At the ICJ, judges are elected for nine year terms and a judge can be re-elected. ${ }^{138} \mathrm{~A}$ nine year term is arguably sufficiently long so as to reduce the risk that a judge's decision-making may be

\footnotetext{
${ }^{134}$ See https://www.theguardian.com/law/2017/nov/20/no-british-judge-on-world-court-for-first-time-in-its71-year-history.

${ }^{135}$ See, https:/ / www.ejiltalk.org/icj-elections-2017-un-general-assembly-and-security-council-elect-fourjudges-to-the-icj-but-fail-to-agree-on-a-fifth-yet-again-trivia-question/.

${ }^{136}$ Keith, supra note 4.

${ }^{137}$ Africa has three seats, GRULAC two seats, Asia three seats, WEOG five seats and Eastern Europe two seats. Due to the P5 convention, traditionally, the seats available to non-P5 members of WEOG and Asia are reduced respectively to two and Eastern Europe to one: Mackenzie et al., supra note 129, at 189-190.

138 ICJ Statute, supra note 21, Art. 13(1).
} 
impermissibly motivated by a conscious or unconscious concern about renewal. To consolidate judicial independence at the ICJ though, the nine year term of an ICJ judge could be made nonrenewable.

Contrasting the judicial appointment process at the $A B$ with the $I C J$, from the perspective of judicial independence, the situation is most precarious. The $A B$ has seven members in total (and three members determine a case), ${ }^{139}$ and members require a consensus at the DSB before their appointment can be confirmed. ${ }^{140}$ This means that even if one WTO member state objects to a nomination, their appointment cannot occur. ${ }^{141}$ Increasingly, despite some express guarantees as to qualifications, ${ }^{142}$ the appointment of $A B$ members has become highly political. As has been pointed out:

it is the DSB that selects AB members, based on an initial screening phase "carried out by a Selection Committee over which powerful WTO Members exert significant influence."...A recent study on $A B$ members' selection process further suggests that over time this process has become more politicized, and that members use their appointment power to influence the endogenous preferences of $A B$ members ex ante...Finally, as Elsig and Pollack note, member states employ some "discursive control" over the WTO judiciary, which underscores the elevated status of the political bodies in the WTO. Thus, "the DSU refers to its highest instance as body (and not a court), which is composed not of judges but of Members" and "writes reports (not judgments)." ${ }^{143}$

Perhaps the most significant breach of the rules on independence are the very short terms of appointment, with $A B$ judges appointed for four year terms that can be renewed once. ${ }^{144}$ Accordingly, judges are objectively under real or perceived external pressures when discharging their judicial function. Alarmingly for the $A B$, its survival is now at stake. The question is whether the $A B$ is a bit too independent for the liking of some member states. This included the blocking of one member of United States nationality in 2011; and in the most recent saga in 2016, the blocking of the South Korean member (Seung Wha Chang). ${ }^{145}$ The United States has blocked the renewal of the South Korean member stating:

The United States is strongly opposed to appellate body members deviating from their appropriate role by restricting the rights or expanding trade agreement obligations... The

\footnotetext{
${ }^{139}$ DSU, Art. 17(1).

${ }^{140}$ DSU, Arts. 2(4) and 17(2).

${ }^{141}$ Other issues concerning the opaque nature of $A B$ appointments and the intrusions into the financial independence of individual judges are noted elsewhere and no more is said here: Dunoff \& Pollack, supra note 1, at 257-258 (notable is that $A B$ members are not entitled to a fixed salary (compromising financial independence); and the DSU does not contain any procedure for the removal of a judge).

${ }^{142}$ Art. 17(3) of the DSU relevantly provides: 'The Appellate Body shall comprise persons of recognized authority, with demonstrated expertise in law, international trade and the subject matter of the covered agreements generally. They shall be unaffiliated with any government. The Appellate Body membership shall be broadly representative of membership in the WTO. All persons serving on the Appellate Body shall be available at all times and on short notice, and shall stay abreast of dispute settlement activities and other relevant activities of the WTO. They shall not participate in the consideration of any disputes that would create a direct or indirect conflict of interest.'

${ }^{143}$ Shany, supra note 2, at 202-203.

${ }^{144}$ DSU, Art. 17(2).

${ }^{145}$ For a detailed discussion, see Dunoff \& Pollack, supra note 1.
} 
United States will not support any individual with a record of restricting trade agreement rights or expanding trade agreement obligations. ${ }^{146}$

As the $A B$ reports do not identify individual members, the United States targeted the South Korean member alleging that 'the reports on which [Mr Chang] participated do not accord with the role of the Appellate Body'; he produced unnecessarily verbose judgments riddled with obiter dicta; and that the 'questions posed by Mr Chang during the hearings showed that certain objectionable excerpts of the AB's reports were ultimately attributable to him. ${ }^{\prime 147}$ Several states have questioned the motives of the United States saying that the real reason why it blocked the appointment of the South Korean member was as retaliation against certain decisions pertaining to 'zeroing' that it did not approve of. ${ }^{148}$

Ultimately, the United States did not approve of how a particular judge went about rendering his judicial function. This purported justification raises several grave concerns, including but not limited to attacks on the individual independence of a judge; but also constitutes an attempt to undermine a judge's decisional independence. After this saga, one can only wonder if $A B$ judges will render decisions that may risk upsetting powerful states. Clearly, at the $A B$, the individual independence of a judge is lacking due to a deficient appointment process in general, and the presence of short judicial terms in particular. This can make permanent the recent demise of the $A B$ itself. At the time of writing, out of a total of seven members, the $A B$ is down to only one member and it cannot perform its functions. ${ }^{149}$ If further appointments are not made in 2020 , the $A B$ may not survive at all. Therefore, it is not an overstatement that the very existence of the $A B$ is in peril. The most important reform to the $A B$ could be to make judicial terms longer and non-renewable. Doing so will not fix each and every structural or institutional design deficit, but will result in enhancing the individual independence of the $A B$ allowing it to adjudicate disputes pursuant to its jurisdictional scheme.

\section{Concluding Remarks: Where to next?}

In this paper, the key independence deficits in the two most significant multilateral international judicial mechanisms are identified. Despite several shortcomings, bearing in mind its jurisdictional scheme, the ICJ model by and large works relatively well. The court was created after much deliberation, and its structural design has ensured that the court possesses the basic degree of independence allowing it to discharge its adjudicative function independently. This does not mean that reforms cannot be pursued to further bolster the court's independence. A degree of realism must be injected into the debate. Only modest reforms that are achievable should be pursued. Specifically, in order of priority: increased transparency in the nomination of ICJ candidates must be promoted; the so-called P5 convention should be abandoned and it may be on its last legs in any event; and a judge's term should be a nine year (or slightly longer) non-renewable term. Even if these limited set of reforms are pursued, achieving which will be no mean feat, the judicial independence of the ICJ will progress considerably.

\footnotetext{
${ }^{146}$ See A. Sarvarian \& F. Fontanelli, 'The USA and Re-Appointment at the WTO: A 'Legitimacy Crisis'?, EJIL Talk' (2016), available at https://www.ejiltalk.org/the-usa-and-re-appointment-at-the-wto-a-legitimacy-crisis/.

$147 \mathrm{lbid}$.

148 Ibid.

${ }^{149}$ See https://www.wto.org/english/tratop_e/dispu_e/ab_members_descrp_e.htm.
} 
In so far as the $A B$ is concerned, its institutional design needs significant reforms. Without such reforms, the $A B$ is unlikely to survive at all. In order of priority, key steps could be to provide for longer non-renewable terms for $A B$ members; consideration should be given to moving away from the consensus rule that creates a veto for individual WTO member states in the appointment of $A B$ members; and enhance the $A B$ 's operational independence. ${ }^{150}$

When the ICJ regime is compared and contrasted to that of the $A B$, the lack of structural guarantees as to judicial independence at the $A B$ make it much more vulnerable to the whims of a particular member state. As a result, in recent times, the $A B$ has proven to be much less stable compared to the $I C$. With respect to the $A B$, perhaps the threshold question needing an answer is whether States even want a truly independent judicial body to determine disputes within the purview of the WTO? Only when an honest answer is given to this question, can the long-term prospects of the $A B$ be fully assessed. If states cannot agree on maintaining a judicial mechanism to adjudicate international trade disputes that possess the most basic degree of independence, then it is preferable to let an adjudicative mechanism vanish for a while. Eventually, the time will come where the spirit of international cooperation returns. When that happens, there will be a real opportunity to build an adjudicative mechanism where a truly independent court or tribunal can be built.

\footnotetext{
${ }^{150}$ Recently, certain proposals by some key WTO member states to address the concerns of the United States have been made. However, those suggestions are not likely to address the independence deficit prevailing for they do not address the structural deficits: See WTO, Communication from the European Union, China, Canada, India, Norway, New Zealand, Switzerland, Australia, Republic of Korea, Iceland, Singapore And Mexico To The General Council, (26 November 2018) WT/GC/W/752. Moreover, it seems that the WTO may be willing to cave into United States' demands regarding the limits to be placed on the $A B$, a move that inspires little confidence that the AB's independence will be secured any time soon: see S. Charnovitz, 'The Attack on the Appellate BodyEvents of 6 December 2019', https://ielp.worldtradelaw.net/2019/12/the-attack-on-the-appellate-body-eventsof-6-december-2019.html.
} 


\section{The Author}

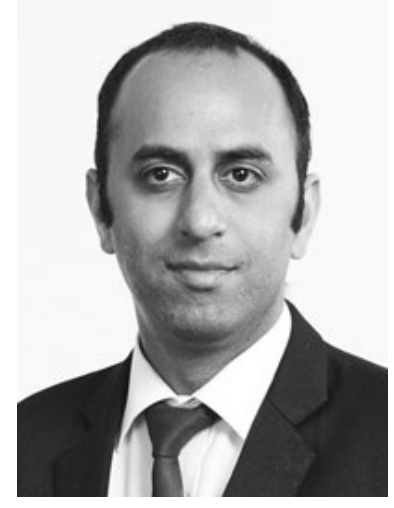

Dr. Rishi Gulati is a Barrister at the Victorian Bar, Australia, and a LSE Fellow in Law at the London School of Economics. He has a doctorate from King's College London, Advanced Masters in Public International Law from Leiden University, and Bachelor of Laws (Honours) from the Australian National University. Rishi researches and teaches in public and private international law. He has previously worked for the Australian Government advising on international law issues and has appeared before several international courts and tribunals. 
The Kolleg-Forschungsgruppe "The International Rule of Law - Rise or Decline?" examines the role of international law in a changing global order. Can we, under the current significantly changing conditions, still observe an increasing juridification of international relations based on a universal understanding of values, or are we, to the contrary, rather facing a tendency towards an informalization or a reformalization of international law, or even an erosion of international legal norms? Would it be appropriate to revisit classical elements of international law in order to react to structural changes, which may give rise to a more polycentric or non-polar world order? Or are we simply observing a slump in the development towards an international rule of law based on a universal understanding of values?

The Research Group brings together international lawyers and political scientists from five institutions in the Berlin-Brandenburg region: Freie Universität Berlin, Hertie School of Governance, Humboldt-Universität zu Berlin, Universität Potsdam and Social Science Research Center Berlin (Wissenschaftszentrum Berlin). An important pillar of the Research Group consists of the fellow programme for international researchers who visit the Research Group for periods up to two years. Individual research projects pursued benefit from dense interdisciplinary exchanges among senior scholars, practitioners, postdoctoral fellows and doctoral students from diverse academic backgrounds.
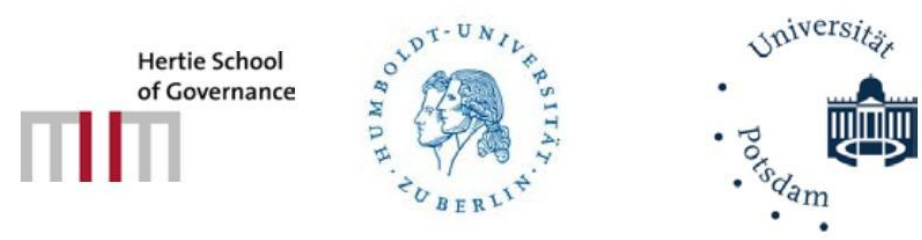